\begin{tabular}{l|l} 
Potaice & e-ISSN: 2655-9404 p-ISSN: 2721-8376 \\
Vol. 3 No. 1, Februari 2020 & DOI: 10.20473/ntr.v3i1.16763 \\
\hline
\end{tabular}

Article history: Submitted 17 Desember 2019; Accepted 6 January 2020; Available online 1 February 2020.

\title{
Eksistensi Putusan MK Nomor 46/PUU/VIII/ 2010 dan Putusan MK Nomor 69/PUU/XIII/2015 Setelah Adanya Undang-Undang Tentang Perkawinan Terbaru
}

\author{
Lidya Mardiana, Sintia Anggrek dan Adeleda Patricia Djimat \\ lidyamardiana1202@gmail.com \\ Universitas Airlangga
}

\begin{abstract}
In October 16th 2019. Indonesian House of Representatives working with Indonesian Presidents legalize 16th Amendment of 2019 Constitution as a change of 1st Amendment of 1974 Constitution about marriage. In 16th Amendment of 2019, a change consist of requirement needed to get married is about the age of marriage. Those change are executed as of The Constitutional Court decision number 22/PII-XV/2017. Before that, there is exist two other decision from The Constitutional Court that related with the 1st Amendment of 1974 Constitution about Marriage, one of which is The Constitutional Court decision number 46/OUU/VIII/2010 about Unmarried Children Status, and decision number 69/PUU/XIII/2015 about marriage agreement that agreed during marriage process. This research analyze about the existence of those two decision after the release of 16th Amendment of 2019 Constitution. This research use two approach, Statute Approach and Conceptual Approach. The main basis in analyzing is 10th and 23rd Verse of 12th Amendment of 2011 Constitution about the law/rule of creating a Constitution law/rule. The results of this research shows that even after the release of 16th Amendment of 2019 Constitution, decision number 46/PUU/VIII/2010 and decision number 69/PUU/XIII/2015 still in effect, as long as there is no change cancellation, nor abolition.

Keywords: The Constitutional Courth Decision; Post Change; Constitution of Marriage.
\end{abstract}

\begin{tabular}{l}
\hline Abstrak \\
\hline Pada tanggal 16 Oktober 2019, DPR dan Presiden mengesahkan Undang-Undang \\
No. 16 tahun 2019 tentang perubahan Undang-Undang Nomor 1 tahun 1974 tentang \\
Perkawinan. Dalam undang-undang No. 16 tahun 2019 tersebut hanya merubah \\
ketentuan mengenai usia kawin. Perubahan tersebut sebagai pelaksanaan atas Putusan \\
Mahkamah Konstitusi Nomor 22/PUU-XV/2017. Diketahui sebelum adanya putusan \\
tersebut, terdapat dua putusan Mahkamah Konstitusi lainnya yang berkaitan dengan \\
Undang-Undang Nomor 1 tahun 1974 tentang Perkawinan, yaitu Putusan Mahkamah \\
KonstitusiNomor 46/PUU/VIII/2010 tentang Status Anak luar Kawin dan Putusan \\
Mahkamah Konstitusi Nomor 69/PUU/XIII/2015 tentang Perjanjian Perkawin yang \\
Dibuat Setelah Perkawinan Berlangsung. Penelitian ini menganalisis tentang eksistensi \\
kedua putusan Mahkamah Konstitusi tersebut pasca terbitnya Undang-Undang No. \\
16 tahun 2019. Pendekatan masalah yang digunakan dalam penelitian ini yaitu Statute \\
Approach dan Conceptual Approach. Landasan utama yang digunakan untuk menganalisis \\
penelitian ini yaitu Pasal 10 dan Pasal 23 Undang-Undang No. 12 tahun 2011 tentang \\
Pembentukan Peraturan Perundang-undangan. Hasil analisis dalam penelitian ini \\
menunjukan Putusan Mahkamah KonstitusiNomor 46/PUU/VIII/2010 dan Putusan \\
Mahkamah KonstitusiNomor 69/PUU/XIII/2015 tetap berlaku sepanjang tidak ada \\
perubahan, pembatalan maupun pencabutan.
\end{tabular} Kata Kunci: Putusan Mahkamah Konstitusi; Pasca Perubahan; Undang-Undang Perkawinan 


\section{Pendahuluan}

Keluarga merupakan ikatan antara laki-laki dan perempuan dalam sebuah perkawinan. Ketika memasuki kehidupan perkawinan, laki-laki dan perempuan memiliki peran baru akibat terjadinya perkawinan tersebut,sehingga mengakibatkan adanya kewajiban-kewajiban diantara mereka. Berdasarkan Badan Kordinasi Keluarga Berencana Nasional (selanjutnya disebut BKKBN) keluarga adalah dua orang atau lebih yang dibentuk berdasarkan ikatan perkawinan yang sah, mampu memenuhi kebutuhan hidup spiritual dan materil yanag layak, bertaqwa kepada Tuhan, memiliki hubungan yang selaras, serasi dan seimbang antara anggota keluarga dan masyarakat serta lingkungannya.

Menurut BKKBN keluarga memiliki fungsi yang senada dengan fungsi keluarga menurut Peraturan Pemerintah Nomor 21 Tahun 1994 tentang Penyelengaraan Pembangunan Keluarga Sejahtera yaitu: ${ }^{1}$

a. Fungsi Keagamaan

Dalam keluarga dan anggotanya didorong dan dikebangkan agar kehidupan keluarga sebagai wahana persemaian nilai-nilai agama dan nilai-nilai luhur budaya bangsa untuk menjadi insan-insan agamais yang penuh iman dan taqwa kepada Tuhan Yang Maha Esa.

b. Fungsi Sosial Budaya

Memberikan kesempatan kepada keluarga dan seluruh anggotanya untuk mengembangkan kekayaan budaya bangsa yang beraneka ragam dalam satu kesatuan.

c. Fungsi Cinta Kasih

Dalam keluarga akan memberikan landasan yang kokoh terhadap hubungan anak dengan anak, suami dengan istri, orang tua dengan anaknyan, serta hubungan kekerabatan antar generasi sehingga keluarga menjadi wadah utama bersemainya kehidupan yang penuh cinta kasih.

d. Fungsi Melindungi

Untuk menumbuhkan rasa aman dan kehangatan.

e. Fungsi Reproduksi

Merupakan mekanisme untuk melanjutkan keturunan yang direncanakan dapat menunjang terciptanya kesejahteraan manusia di dunia yang penuh iman dan taqwa.

f. Fungsi Sosialisasi dan Pendidikan

Memberikan peran kepada keluarga untuk mendidik keturunan agar bisa

1 Penjelasan Pasal 4 ayat (2) Peraturan Pemerintah Nomor 21 Tahun 1994 
melakukan penyesuaian dengan alam kehidupannya dimasa depan.

g. Fungsi Ekonomi

Menjadi unsur pendukung kemandirian dan ketahanan keluarga.

h. Fungsi Pembinaan Lingkungan

Memberikan pada setiap keluarga kemampuan menempatkan diri secara serasi, selaras, dan seimbang sesuai daya dukung alam dan lingkungan yang berubah secara dinamis.

Berdasarkan fungsi keluarga yang telah disebutkan diatas, bahwa perkawinan tidak hanya malahirkan ikatan lahir batin namun juga melahirkan hubungan-hubungan keperdataan anatara laki-laki dan perempuan dalam membentuk keluarga. Oleh karena itu, untuk mengatur hubungan-hubungan tersebut pemerintah pada Tahun 1974 mengeluarkan Undang-Undang Nomor 1 Tahun 1974 Tentang Perkawinan (selanjutnya disebut UU Perkawinan).

Perkawinan merupakan salah satu peristiwa penting yang terjadi dalam kehidupan manusia. Berdasarkan ketentuan Pasal 1 Undang-Undang Nomor 16 Tahun 2019 Tentang Perubahan Atas Undang-Undang Nomor 1 Tahun 1974 Tentang Perkawinan mengatur "perkawinan ialah ikatan lahir bathin antara seorang laki-laki dengan perempuan sebagai suami istri dengan tujuan membentuk keluarga yang bahagia dan kekal berdasarkan Ketuhanan Yang Maha Esa". Pengertian perkawinan di dalam ketentuan Pasal 1 UU Perkawinan dapat disimpulkan bahwa perkawinan tidak hanya urusan perbuatan keagamaan tetapi merupakan perbuatan hukum.

Tujuan diaturnya perkawinan dalam suatu undang-undang adalah tertib masyarakat dibidang hukum keluarga dan perkawinan, dalam arti tingkah laku anggota masyarakat untukmemenuhi kebutuhannya dalam hal perkawinan terpola dalam suatu sistem kaedah dan oleh Sudikno Mertokusumi dijelaskan bahwa kaedah hukum lazimnya diartikan sebagai peraturan hidup yang menentukan bagaiman manusia seyogyanya berperilaku, bersikap didalam masyarakat agar kepentingan-kepentingan orang lain terlindungi dan fungsi kaedah hukum pada hakekatnya adalah melindungi kepentingan manusia atau kelompok manusia, 
kemudian tujuannya adalah ketertiban masyarakat. ${ }^{2}$ Oleh sebab itu seiring dengan perubahan manusia yang dinamis, maka hukum juga harus dapat menjangkau setiap permasalahan yang terjadi dalam masyarakat sehingga hukum tersebut dapat memberikan kepastian hukum bagi masyarakat.

Meskipun UU Perkawinan ini sudah berlaku selama 45 tahun sejak diundangkan UU Perkawinan ini, bukan berarti tidak ada masalah-masalah yang muncul terkait perkawinan yang terjadi dalam masyarakat. Masalah-masalah yang muncul berkaitan dengan perkawinan ini dapat diakibatkan karena didalam UU Perkawinan belum mengatur hal-hal yang berkaitan dengan masalah yang terjadi di masyarakat akibat perkembangan yang terjadi didalam masyarakat sehingga muncul masalah-masalah baru yang harus diatur dalam UU Perkawinan tersebut seperti hubungan hukum anak luar kawin, perjanjian perkawinan, dan batas usia kawin yang menjadi masalah kontroversial bagi kalangan hukum. Didasarkan permasalahan-permasalahan yang terjadi dalam masyarakat, maka dapat diajukan pengujian kembali (Judicial Review) atas UU perkawinan tersebut kepada lembaga negara yang memiliki kewenangan untuk menguji UndangUndang tersebut terhadap Undang-Undang Dasar 1945.

Terkait lembaga negara, dalam rangka Perubahan Pertama sampai Perubahan Keempat UUD 1945, bangsa Indonesia telah mengadopsikan prinsip-prinsip baru dalam sistem ketatanegaraan, yaitu antara lain prinsip pemisahan kekuasaan dan 'checks and balances> sebagai penggganti sistem supremasi parlemen yang berlaku sebelumnya. Menurut Menurut Jimly Asshiddiqie, dengan perubahan tersebut, prinsip negara hukum yang dianut dipertegas dengan: ${ }^{3}$

a) Diaturnya mekanisme penegakan hukum dimulai dari penegakan konstitusi sebagai hukum tertinggi Sebagai akibat perubahan itu;

b) Dipandang perlu untuk diadakan mekanisme guna memutus sengketa kewenangan yang mungkin terjadi antar lembaga-lembaga yang mempunyai

\footnotetext{
${ }^{2}$ Samson Rahman, Islam Moderat Menebar Islam Rahmatan Lil Alamin (Pustaka Ikadi 2007).[11].

${ }^{3}$ Jimly Asshiddiqie, 'Kedudukan Mahkamah Konstitusi Dalam Struktur Ketatanegaraan Indonesia' [2015] Berita Mahkamah Konstitusi Republik Indonesia. 3
} 
kedudukan yang satu sama lain bersifat sederajat, yang kewenangannya ditentukan dalam UUD;

c) Perlu dilembagakanadanya peranan hukum danhakim yang dapat mengontrol proses dan produk keputusan-keputusan politik yang hanya mendasarkan diri pada prinsip 'majority rule'.

Dalam ketentuan Undang-Undang Dasar Negara Republik Indonesia Tahun 1945 pasca Perubahan Keempat mengatur bahwa dalam struktur kelembagaan Republik Indonesia terdapat (setidaknya) 9 (sembilan) organ negara yang secara langsung menerima kewenangan langsung dari Undang-Undang Dasar, yaitu:

i. Dewan Perwakilan Rakyat;

ii. Dewan Perwakilan Daerah;

iii. Majelis Permusyawaratan Rakyat;

iv. Badan Pemeriksa Keuangan;

v. Presiden;

vi. Wakil Presiden;

vii. Mahkamah Agung;

viii. Mahkamah Konstitusi; dan

ix. Komisi Yudisial.

Mahkamah Konstitusi Republik Indonesia adalah lembaga (tinggi) negara yang baru yang sederajat dan sama tinggi kedudukannya dengan Mahkamah Agung (MA). Mahkamah Konstitusi dan Mahkamah Agung samasama merupakan pelaksana cabang kekuasaan kehakiman yang merdeka dan terpisah dari cabang-cabang kekuasaan lain, yaitu pemerintah dan lembaga permusyawaratan-perwakilan. Struktur kedua organ kekuasaan kehakiman ini terpisah dan berbeda sama sekali satu sama lain. Namun, keduanya samasama merupakan pelaku kekuasaan kehakiman menurut ketentuan Pasal 24 ayat (2) UUD 1945. Mahkamah Konstitusi berfungsi sebagai pengawal UUD (the guardian of the constitution), sedangkan Mahkamah Agung merupakan pengawal UU dan peraturan perundang-undangan lainnya. Selain hal tersebut, Mahkamah Agung sebagai puncak peradilan (upaya hukum) yang berkaitan dengan tuntutan perjuangan keadilan bagi orang per orang atau pun subjek hukum lainnya, sedangkan Mahkamah Konstitusi tidak berurusan dengan orang per orang, melainkan dengan kepentingan umum yang lebih luas. Perkara- perkara yang 
diadili di Mahkamah Konstitusi pada umumnya menyangkut persoalan- persoalan kelembagaan negara atau institusi politik yang menyangkut kepentingan umum yang luas atau pun berkenaan dengan pengujian terhadap norma-norma hukum yang bersifat umum dan abstrak, bukan urusan orang per orang atau kasus demi kasus ketidakadilan secara individual dan konkrit.

Hubungan antara Mahkamah Konstitusi dengan Mahkamah Agung juga terkait dengan materi perkara pengujian undang-undang. Setiap perkara yang telah diregistrasi wajib diberitahukan kepada Mahkamah Agung, agar pemeriksaan atas perkara pengujian peraturan di bawah undang-undang yang bersangkutan oleh Mahkamah Agung dihentikan sementara sampai putusan atas perkara pengujian undang-undang yang bersangkutan dibacakan oleh Mahkamah Konstitusi. Hal ini dimaksudkan agar tidak terjadi pertentangan antara pengujian undang-undang yang dilakukan oleh Mahkamah Konstitusi dengan pengujian peraturan di bawah undang- undang yang dilakukan oleh Mahkamah Agung. Karena itu, dalam memeriksa undang-undang yang diajukan pengujiannya, Mahkamah Konstitusi harus memperhatikan dan mempertimbangkan dengan sungguh-sungguh keterangan, baik lisan mau pun tertulis dari pihak Dewan Perwakilan Rakyat sebagai pembentuk Undang- Undang.

Berkaitan dengan UU Perkawinan, terdapat beberapa putusan Mahkamah Konstitusi yang telah berkekuatan hukum tetap dan berlaku serta menjadi rujukan hakim dalam menyelesaikan sengketa terkait yaitu Putusan Mahkamah Konstitusi Nomor 46/PUU/VIII/ 2010 tentang status anak luar kawin dan Putusan Mahkamah Konstisusi Nomor 69/PUU/XIII/2015 tentang Perjanjian Perkawinan Yang Dibuat Setelah Perkawinan Berlangsung dan yang terakhir Putusan Mahkamah Konstitusi Nomor 22/PUU-XV/2017 tentang Minimal Usia Perkawinan Pada Perempuan. Namun pada Putusan Mahkamah Konstitusi Nomor 22/PUU-XV/2017 mengharuskan adanya perubahan pada UU Perkawinan. Sehingga Dewan Perwakilan Rakyat (DPR) sebagai lembaga legislatif mempunyai tugas dan wewenang untuk membuat dan/atau melakukan perubahan terhadap peraturan perundang-undangan. 
UU Perkawinan menjadi salah satu agenda pembahasan DPR periode 20142019. DPR dan Pemerintah telah menyetujui bersama RUU tentang Perubahan atas UU Perkawinan untuk disahkan menjadi Undang-Undang. DPR dan Pemerintah melakukan perubahan dan penambahan pasal didalam UU Perkawinan, sebagaimana terdapat dalam konsideran UU Perkawinan, perubahan UU Perkawinan dilakukan sebagai pelaksanaan atas Putusan Mahkamah Konstitusi Nomor 22/PUU-XV/2017 tentang Minimal Usia Perkawinan Pada Perempuan karena menurut Putusan Mahkamah Konstitusi tersebut batas usia kawin 16 tahun bagi perempuan dan 19 tahun bagi laki-laki adalah diskriminasi. Adapun perubahan pada UU Perkawinan terkait batas usia minimum perkawinan di dalam ketentuan Pasal 7 ayat (1) UU Perkawinan yang semula disebutkan "perkawinan hanya diizinkan bila pihak laki-laki sudah mencapai 19 tahun dan pihak perempuan sudah mencapai 16 tahun" namun setelah adanya perubahan Pasal 7 ayat (1) UU Perkawinan disebutkan perkawinan hanya diizinkan apabila pria dan wanita sudah mencapai 19 tahun.

Menurut Maria Farida Indrati bahwa putusan mahkamah salah satu bentuk hukum melalui sarana rekayasa ( law as a tool of social engineering) dalam perkara a quo akan memberikan dampak pada perubahan berupa penyesuaian dalam pelaksanaan dalam undang-undang perkawinan. ${ }^{4}$ Terkait dengan perubahan pada UU Perkawinan tersebut dinilai kurang lengkap karena mengesampingkan dengan tidak menindak lanjuti Putusan Mahkamah Konstitusi Nomor 46/PUU/ VIII/ 2010 tentang status anak luar kawin dan Putusan Mahkamah Konstisusi Nomor 69/PUU/XIII/2015 tentang Perjanjian Perkawinan Yang Dibuat Setelah Perkawinan Berlangsung.

Penelitian ini menggunakan penelitian yuridis Normatif yaitu penelitian ini mengacu pada peraturan perundang-undangan, buku-buku, bahan-bahan bacaan dan literatur yang berkaitan dengan penelitian ini. Adapun pendekatan yang digunakan yaitu metode statute approach dan conceptual approach. Statute approach

${ }^{4}$ Putusan Mahkamah Konstisusi Nomor 22/PUU-XV/2017. 
yaitu pendekatan undang-undang yang dilakukan dengan menelaah undangundang yang dipergunakan sebagai dasar dalam penelitian ini. ${ }^{5}$ Conceptual approach yaitu beranjak dari pandangan-pandangan dan donktirn-dokrin yang berkambang didalam ilmu hukum. ${ }^{6}$ Bahan hukum yang digunakan dalam penelitian terdiri dari bahan hukum primer yaitu Undang-Undang Dasar 1945, Undang-Undang Nomor 11 Tahun 2012 tentang Hirarki Peraturan Perundangundangan, Perubahan Undang Undang Nomor 16 Tahun 2019 tentang Perubahan atas Undang-Undang Nomor 1 Tahun 1974 tentang Perkawinan, Putusan Mahkamah Konstitusi, sedangkan bahan hukum sekunder yaitu buku, tesis, jurnal, dan dokumen-dokumen yang berkaitan dengan penelitian ini.

Penelitian ini menggunakan penelitian yuridis Normatif yaitu penelitian ini mengacu pada peraturan perundang-undangan, buku-buku, bahan-bahan bacaan dan literatur yang berkaitan dengan penelitian ini. Pendekatan yang digunakan dalam penelitian ini adalah metode statute approach dan conceptual approach. Statute approach yaitu pendekatan undang-undang yang dilakukan dengan menelaah undang-undang yang dipergunakan sebagai dasar dalam penelitian ini. ${ }^{7}$ Conceptual approach yaitu beranjak dari pandangan-pandangan dan donktirndokrin yang berkambang didalam ilmu hukum. ${ }^{8}$ Bahan hukum yang digunakan dalam penelitian terdiri dari bahan hukum primer yaitu Undang-Undang Dasar 1945, Undang-Undang Nomor 11 Tahun 2012 tentang Hirarki Peraturan Perundang-undangan, Perubahan Undang Undang Nomor 16 Tahun 2019 tentang Perubahan atas Undang-Undang Nomor 1 Tahun 1974 tentang Perkawinan, Putusan Mahkamah Konstitusi, sedangkan bahan hukum sekunder yaitu buku, tesis, jurnal, dan dokumen-dokumen yang berkaitan dengan penelitian ini.

Adapun tujuan dari penelitian ini adalah untuk mengetahui eksistensi Putusan Mahkamah Konstitusi Nomor 46/PUU/VIII/ 2010 dan Putusan Mahkamah Konstitusi Nomor 69/PUU/XIII/2015 setelah adanya Perubahan

\footnotetext{
${ }^{5}$ Peter Mahmud Marzuki, Penelitian Hukum (2010). [93].

6 ibid.[95].

7 ibid.[93].

8 ibid.[95].
} 
Undang Undang Nomor 16 Tahun 2019 tentang Perubahan atas Undang-Undang Nomor 1 Tahun 1974 tentang Perkawinan.

\section{Putusan Mahkamah Konstitusi Sebagai Bentuk Hukum Melalui Sarana Rekayasa Sosial}

Menurut ketentuan Undang-undang Dasar Negara Republik Indonesia Tahun 1945 pasca perubahan keempat (Tahun 2002) dalam struktur kelembagaan Republik Indonesia terdapat setidaknya 9 (Sembilan) buah organ negara yang secara langsung menerima kewenangan langsung dari Undang-Undang Dasar, diantaranya yaitu Mahkamah Konstitusi. Mahkamah Konstitusi Republik Indonesia adalah lembaga (tinggi) negara yang baru yang sederajat dan sama tinggi kedudukannya dengan Mahkamah Agung (MA).Mahkamah Konstitusi dan Mahkamah Agung samasama merupakan pelaksana cabang kekuasaan kehakiman (judiciary) yang merdeka dan terpisah dari cabang-cabang kekuasaan lain, yaitu pemerintah (executive) dan lembaga permusyawaratan-perwakilan (legislature).

Pembentukan Mahkamah Konstitusi tidak dapat dilepaskan dari perkembangan hukum dan ketatanegaraan tentang pengujian produk hukum oleh lembaga peradilan atau judicial review. ${ }^{9}$ Berdasarkan ketentuan Pasal 10 ayat (1) Undang-Undang Nomor 24 Tahun 2003tentang Mahkamah Konstitusi, mengatur mengenai wewenang Mahkamah Konstitusi sebagai berikut:

1) Mahkamah Konstitusi berwenang mengadili pada tingkat pertama dan terakhir yang putusannya bersifat final untuk:

a. Menguji undang-undang terhadap Undang-Undang dasar Negara Republik Indonesia Tahun 1945;

b. Memutus sengketa kewenangan lembaga negara yang kewenangannya diberikan oleh Undang-Undang Dasar Negara Republik Indonesia Tahun 1945;

c. Memutus pembubaran partai politik; dan

d. Memutus perselisihan tentang hasil pemilihan umum.

${ }^{9}$ Oly Viana Agustine, 'Politik Hukum Perjanjian Perkawinan Pasca Putusan Mahkamah Konstitusi Nomor 69/PUU/XIII/2015 Dalam Menciptakan Keharmonisan Perkawinan' (2017) 06 Rechts Vinding.[57]. 
Berkaitan dengan dasar hukum tersebut, kompetensi Mahkamah Konstitusi Indonesia dalam Judicial Review merupakan pengujian undang-undang terhadap Undang-Undang Dasar Negara Republik Indonesia 1945 yang dilakukan secara konstitusionalitas suatu undang-undang, yaitu menguji sejauhmana undangundang tersebut bersesuai atau bertentangan dengan Undang-Undang Dasar.

Menurut Bactiar, pengujian konstitusionalitas undang-undang dapat dilakukan secara formal (formele toesing) atau secara materiel (materiele toetsing) .Pengujian secara formal adalah pengujian yang berkaitan dengan apakah proses pembuatan undang-undang telah sesuai atau tidak dengan prosedor yang ditetapkan. Sementara pengujian secara material adalah pengujian yang berkaitan dengan isi atau substansi dari suatu undang-undang. ${ }^{10}$ Sesuai berdasarkanpada Pasal 51 ayat (3) Undang-Undang Nomor 24 Tahun 2003 tentang Mahkamah Konstitusi, yang berbunyi:

“Dalam permohonan sebagaimana dimaksud pada ayat (2), pemohon wajib menguraikan dengan jelas bahwa:

a. Pembentukan undang-undang tidak memenuhi ketentuan berdasarkan Undang-Undang Dasar Negara Republik Indonesia Tahun 1945: dan/atau

b. Materi muatan dalam ayat, pasal, dan/atau bagian undang-undang dianggap bertentang dengan Undang-Undang Dasar Negara Republik Indonesia Tahun $1945^{\prime \prime}{ }^{11}$

Dalam hal suatu pembentukan undang-undang tidak memenuhi ketentuan berdasarkan Undang-Undang Dasar maka undang-undang tersebut dinyatakan tidak mempunyai kekuatan hukum mengikat oleh Putusan Mahkamah Konstitusi. Sedangkan, jika suatu materi muatan ayat, pasal dan/atau bagian undang-undang dinyatakan bertentangan dengan Undang-Undang Dasar, maka materi muatan ayat, pasal dan/atau bagian undng-undang tersebut tidak lagi mempunyai kekuatan hukum mengikat oleh Putusan Mahkamah Konstitusi.

Putusan Mahkamah Konstitusi sebagai hasil judicia review bersifat final dan mengikat Putusan Mahkama Konstitusi yang mengabulkan judicial review

\footnotetext{
${ }^{10}$ Bactiar, Problematika Implementasi Putusan Mahkamah Konstitusi Pada Pengujian UU Terhadap UUD (Raih Asa Sukses 2015).[133].

${ }^{11}$ Undang-Undang Nomor 24 Tahun 2003tentang Mahkamah Konstitusi
} 
Undang-maupun seluruhnya, dengan sendirinya telah mengubah ketentuan suatu Undang-Undang dengan menyatakan bertentangan dengan Undang-Undang Dasar 1945 dan tidak memiliki kekuatan hukum mengikat hal ini berarti sejak pembacaan putusan tersebut ketentuan Undang-Undang yang dibacakan tidak berlaku lagi sehingga setiap penyelenggara dan warga negara tidak dapat lagi menjadikan sebagai dasar hukum kebijakan atau tindakan. ${ }^{12}$ Putusan Mahkamah Konstitusi dapat dibedakan menjadi 2 (dua) yaitu putusan Mahkamah Konstitusi yang langsung dapat dilaksanakan "excecutable" dan putusan Mahkamah Konstitusi yang memerlukan tindak lanjut dengan pembentukan undang-undang atas perubahan undang-undang yang bersangkutan. ${ }^{13}$ Dengan kata lain, putusan Mahkamah Konstitusi tersebut dapat langsung dilaksanakan dan karena sifat hukum secara publik maka putusan Mahkamah Konstitusi berlaku bagi siapa saja, tidak hanya berlaku bagi para pihak yang melakukan judicial review. Sebagaimana disebutkan dalam pasal 10 ayat (1) berikut penjelasan Undang-Undang Nomor 8 Tahun 2011 tentang perubahan Undang-Undang Nomor 24 Tahun 2003 tentang Mahkamah Konstitusi yang berbunyi putusan Mahkamah Konstitusi bersifat final yakni Mahkamah Konstitusi langsung memperoleh kekuatan hukum sejak diucapkan dan tidak ada upaya hukum yang dapat ditempuh. sifat final dalam Putusan MahkamahKonstitusi dalam Undang-Undang ini mencakup pula kekuatan hukum mengikat (final dan binding).

Berdasarkan pendapat Maria Faria Indrati, putusan Mahkamah Konstitusi merupakan suatu bentuk hukum melalui sarana rekayasa sosial (law as a tool of social engineering). ${ }^{14}$ Sarana rekayasa sosial merupakan teori yang dikemukakan oleh Roscoe Pound, yang berarti hukum sebagai alat pembaharuan/ merekayasa dalam masyarakat, dalam istilah ini hukum diharapkan dapat berperan merubah nilai-nilai sosial dalam masyarakat. ${ }^{15}$ Hukum yang digunakan sebagai

\footnotetext{
${ }^{12}$ Op.cit, [55-56]

${ }^{13}$ Qomaruddin, ‘Pembentukan Undang-Undang Dalam Perspektif Putusan Mahkamah Konstitusi' (2009) 6 Legislasi Indonesia.[701].

${ }^{14}$ Putusan Mahkamah Konstisusi Nomor 22/PUU-XV/2017

${ }^{15}$ Nazaruddin lathif, 'Teori Hukum Sebagai Sarana/ Alat Untuk Memperbaharui Atau Merekayasa Masyarakat' (2017) 03 Pakuan Law Review. [81].
} 
sarana pembaharuan itu dapat berupa undang-undang atau yurisprudensi atau kombinasi keduanya. Di Indonesia yang paling menonjol adalah perundangundangan, yurisprudensi juga berperan namun tidak sebanyak perundangundangan. agar supaya dalam pelaksanaan perundang-undangan yang bertujuan untuk pembaharuan itu dapat berjalan sebagaimana mestinya, hendaknya perundang-undangan yang dibentuk itu sesuai dengan apa yang menjadi inti pemikiran aliran sociological jurisprudence yaitu hukum yang baik hendaknya sesuai dengan hukum yang hidup didalam masyarakat. ${ }^{16}$

Maksud dengan Yurisprudensi adalah keputusan-keputusan dari hakim terdahulu untuk menghadapi suatu perkara yang tidak diatur dalam ketentuan undang-undang dan menjadi pedoman bagi para hakim yang lain untuk menyelesaikan suatu perkara yang sama. Yurisprudensi merupakan produk hukum dari lembaga yudikatif. Dengan demikian, Putusan Putusan Mahkamah Konstitusi merupakan salah satu bentuk yurisprudensi sehingga dapat menjadi bentuk sarana rekayasa sosial memberikan dampak perubahan pada pelaksanaan Undang-Undang yang diujikan melalui judicial review bisa berupa penyesuaian dalam pelaksanaan Undang-Undang tersebut.

\section{Putusan Mahkamah Konstisusi Nomor 46/PUU/VIII/ 2010 Tentang Status Anak}

\section{Luar Kawin}

J. Satrio Kemukakan bahwa menurut doktrin serta ketentuan yang ada dalam KUHPerdata anak luar kawin dapat dibedakan menjadi anak luar kawin dalam arti luas dan arti sempit. Anak luar kawin dalam arti luas meliputi anak zina adalah anak-anak yang dilahirkan dari hubungan luar kawin, anatara seorang laki-laki dan seorang perempuan dimana salah satunya atau keduanya terikat perkawinan dengan orang lain dan anak sumbang adalah anak-anak yang dilahirkan dari hubungan seorang laki-laki dan seorang perempuan yang antara keduanya ada larangan menurut undang-undang untuk saling mekawin. Anak

\footnotetext{
${ }^{16}$ Lili Rasjidi \&Ira Thania Rasjidi, Pengantar Filsfat Hukum (2007).[74].
} 
luar kawin dalam arti sempit adalah anak yang dilahirkan dari hasil hubungan antara seorang laki-laki dan seorang perempuan yang keduanya tidak terikat perkawinan dengan orang lain dan tidak ada larangan unutk saling mekawin, dengan kata lain anak luar kawin dalam arti sempit ini adalah anak-anak yang tidak sah selain anak zina dan anak sumbang. ${ }^{17}$

Anak yang lahir di luar kawin memiliki dampak negatif bagi anak dimata hukum. Status anak yang dilahirkan akan menjadi tidak pasti karena tidak ada buki otentik yang dapat menguatkan dirinya bahwa dia adalah anak yang sah dari kedua orang tuanya, kedudukan dimata hukum juga dianggap tidak sah dari kedua orang tuanya. Konsekuensinya anak tersebut hanya mempunyai hubungan perdata dengan ibu dan keluarga ibunya, anak tersebut tidak mempunyai hubungan hukum terhadap ayah biologisnya. ${ }^{18}$

Oleh karena itu UU Perkawinan dinggap tidak mencerminkan rasa keadilan di masyarakat dan secaraa objektif-empiris telah memasung hak konstitusional untuk memperoleh kepastian hukum dan terbebas dari rasa cemas, ketakutan dan diskriminasi terkait perkawinan dan status hukum anak. Sehingga UU Perkawinan menimbulkan ketidakpastian hukum yang mengakibatkan kerugian bagi masyarakat khususnya yang berkaitan dengan status perkawinan dan status anak yang dihasilkan dari hasil perkawinan.Hal ini dianggap menjadi tidak benar jika norma hukum UU Perkawinan menyatakan seorang anak di luar perkawinan hanya mempunyai hubungan perdata dengan ibunya dan keluarga ibunya, karena berpijak pada sah atau tidaknya suatu perkawinan menurut norma hukum.

Putusan Mahkamah Konstisusi Nomor 46/PUU/VIII/ 2010 menguji konstitusionalitas Pasal 2 ayat (2) UU Perkawinanan yang menyatakan “tiaptiap perkawinan dicatatkan menurut peraturan perundang-undangan yang berlaku" dan Pasal 43 ayat (1) UU Perkawinanmenyatakan "anak yang lahir luar perkawinan hanya mempunyai hubungan perdata dengan ibunya dan keluarga

${ }^{17}$ Ahmad Dedy Aryanto, 'Perlindungan Hukum Anak Luar Nikah Di Indonesia' (2015) 9 Bilancia <file:/ / Users/mariajuanda/Downloads/283-Article Text-352-1-10-20180728.pdf>.[125-126].

18 ibid. [123]. 
ibunya" khususnya mengenai hak untuk mendapatkan status hukum anak.

Mengenai anak yang dilahirkan di luar perkawinan adalah mengenai makna hukum (legal meaning) frasa "yang dilahirkan di luar perkawinan" secara alamiah tidaklah mungkin seorang perempuan hamil tanpa terjadinya pertemuan antara ovum dan spermatozoa baik melalui hubungan seksual (coitus) maupun cara lain berdasarkan perkembangan tekNomorlogi yang menyebabkan terjadinya pembuahan. Oleh karena itu, tidak tepat dan tidak adil manakala hukum menetapkan bahwa anak yang lahir dari suatu kehamilan karena hubungan seksual luar perkawinan hanya memiliki hubungan dengan perempuan tersebut sebagai ibunya adalah tidak tepat dan tidak adil pula jika hukum membebaskan laki-laki yang melakukan hubungan seksual yang menyebabkan terjadinya kehamilan dan kalahiran anak tersebut dari tanggung jawabnya sebagai bapak dan bersama dengan itu hukum meniadakan hak-hak terhadap laki-laki tersebut sebagai bapaknya, lebih-lebih manakala berdasarkan teknologi yang ada memungkinkan dapat dibuktikan bahwa seorang anak itu merupakan anak dari laki-laki tertentu.

Berdasarkan uraian diatas, hubungan anak dengan laki-laki sebagai bapak tidak semata-mata karena adanya ikatan perkawinan, akan tetapi dapat juga didasarkan pada adanya hubungan darah anataraanak dengan laki-laki tersebut sebagai bapak. Sehingga Pasal 43 ayat (1) UU Pekawinan bertentangan dengan UUD 1945 secara bersyarat (conditionally unconstitutional) yakni inkonstitusional sepanjang ayat tersebut dimaknai menghilangkan hubungan perdata dengan laki-laki yang dapat dibuktikan berdasarkan teknologi dan/atau alat bukti lain menurut hukum mempunyai hubungan darah sebagai ayahnya sehingga Pasal 43 ayat (1) UU Pekawinan tersebut harus dibaca "anak yang lahir luar perkawinan mempunyai hubungan perdata dengan ibunya dan keluarga ibunya serta dengan laki-laki sebagai ayahnya yang dapat dibuktikan berdasarkan ilmu pengetahuan dan teknologi dan/atau alat bukti lain menurut hukum mempunyai hubungan darah, termasuk hubungan perdata dengan keluarga ayahnya". ${ }^{19}$

${ }^{19}$ Putusan Mahkamah Konstisusi Nomor 46/PUU/VIII/ 2010. 


\section{Putusan Mahkamah Konstitusi Nomor 69/PUU/XIII/2015 Tentang Perjanjian} Perkawinan Yang Dibuat Setelah Perkawinan Berlangsung

Sebelum adanya Putusan Mahkamah Konstitusi Nomor 69/PUU/ XIII/2015, ketentuan mengenai pembuatan perjanjian perkawinan yang diatur dalam UU Perkawinan tidak mengatur mengenai pembuatan perjanjian perkawinan sesudah berlangsung perkawinan. Namun pasca keluar Putusan Mahkamah Konstitusi Nomor 69/PUU/XIII/2015 tanggal 21 Maret 2016 terjadi perubahan yang berkaitan dengan perubahan perjanjian perkawinan. Putusan tersebut diajukan oleh pemohon yaitu Ny. Ike Farida yang melakukan perkawinan campuran.

Ketentuan yang dimohonkan kepada Mahkamah Konstitusi adalah ketentuan dalam Pasal 21 ayat (1) dan Pasal 36 ayat(1) UUPA lalu ketentuan Pasal 29 ayat (1), (3), (4) dan Pasal 35 ayat (1) UU Perkawinan. Dalam putusannya, Mahkamah Konstitusi menyatakan Pasal 29 ayat (1) UU Perkawinan bertentangan dengan UUD 1945 sepanjang tidak dimaknai "Pada waktu, sebelum dilangsungkan atau selama dalam ikatan perkawinan kedua belah pihak atas persetujuan bersama dapat mengajikam perjanjian tertulis yang disahkan oleh pegawai pencatat perkawinan atau Nomortaris setelah mana isinya berlaku juga terhadap pihak ketiga sepanjangan pihak ketiga tersebut tersangkut".

Pada dasarnya Putusan Mahkamah Konstitusi tersebut telah merubah norma dan tatanan perjanjian perkawinan yang terdapat dalam Pasal 29 UU Perkawinan, sehingga substansi Pasal 29 berubah menjadi sebagai berikut $:^{20}$

1. Pasal 29 ayat (1) Undang-Undang Nomor 1 Tahun 1974 tentang Perkawinan (Lembaran Negara Republik Indonesia Tahun 1974 Nomor 1, Tambahan Lembaran Negara Republik Indonesia Nomor 3019) bertentangan dengan Undang-Undang Dasar Negara Republik Indonesia Tahun 1945 sepanjang tidak dimaknai "Pada waktu, sebelum dilangsungkan atau selama dalam ikatan perkawinan kedua belah pihak atas persetujuan bersama dapat mengajukan perjanjian tertulis yang disahkan oleh pegawai pencatat perkawinan atau Notaris, setelah mana isinya berlaku juga terhadap pihak ketiga sepanjang pihak ketiga tersangkut";

${ }^{20}$ Putusan Mahkamah Konstitusi Nomor 69/PUU-XIII/2015 
2. Pasal 29 ayat (1) Undang-Undang Nomor 1 Tahun 1974 tentang Perkawinan (Lembaran Negara Republik Indonesia Tahun 1974 Nomor 1, Tambahan Lembaran Negara Republik Indonesia Nomor 3019) tidak mempunyai kekuataan hukum mengikat sepanjang tidak dimaknai "Pada waktu, sebelum dilangsungkan atau selama dalam ikatan perkawinan kedua belah pihak atas persetujuan bersama dapat mengajukan perjanjian tertulis yang disahkan oleh pegawai pencatat perkawinan atau Notaris, setelah mana isinya berlaku juga terhadap pihak ketiga sepanjang pihak ketiga tersangkut";

3. Pasal 29 ayat (3) Undang-Undang Nomor 1 Tahun 1974 tentang Perkawinan (Lembaran Negara Republik Indonesia Tahun 1974 Nomor 1, Tambahan Lembaran Negara Republik Indonesia Nomor 3019) bertentangan dengan Undang-Undang Dasar Negara Republik Indonesia Tahun 1945 sepanjang tidak dimaknai "Perjanjian tersebut mulai berlaku sejak perkawinan dilangsungkan, kecuali ditentukan lain dalam Perjanjian Perkawinan";

4. Pasal 29 ayat (3) Undang-Undang Nomor 1 Tahun 1974 tentang Perkawinan (Lembaran Negara Republik Indonesia Tahun 1974 Nomor 1, Tambahan Lembaran Negara Republik Indonesia Nomor 157 3019) tidak mempunyai kekuatan hukum mengikat sepanjang tidak dimaknai "Perjanjian tersebut mulai berlaku sejak perkawinan dilangsungkan, kecuali ditentukan lain dalam Perjanjian Perkawinan";

5. Pasal 29 ayat (4) Undang-Undang Nomor 1 Tahun 1974 tentang Perkawinan (Lembaran Negara Republik Indonesia Tahun 1974 Nomor 1, Tambahan Lembaran Negara Republik Indonesia Nomor 3019) bertentangan dengan Undang-Undang Dasar Negara Republik Indonesia Tahun 1945 sepanjang tidak dimaknai "Selama perkawinan berlangsung, perjanjian perkawinan dapat mengenai harta perkawinan atau perjanjian lainnya, tidak dapat diubah atau dicabut, kecuali bila dari kedua belah pihak ada persetujuan untuk mengubah atau mencabut, dan perubahan atau pencabutan itu tidak merugikan pihak ketiga";

6. Pasal 29 ayat (4) Undang-Undang Nomor 1 Tahun 1974 tentang Perkawinan (Lembaran Negara Republik Indonesia Tahun 1974 Nomor 1, Tambahan Lembaran Negara Republik Indonesia Nomor 3019) tidak mempunyai kekuatan hukum mengikat sepanjang tidak dimaknai "Selama perkawinan berlangsung, perjanjian perkawinan dapat mengenai harta perkawinan atau perjanjian lainnya, tidak dapat diubah atau dicabut, kecuali bila dari kedua belah pihak ada persetujuan untuk mengubah atau mencabut, dan perubahan atau pencabutan itu tidak merugikan pihak ketiga";

Putusan ini telah memperluas waktu pembuatan perjanjian perkawinan. Selama ini, UU Perkawinan hanya mengatur perjanjian prakawin (prenuptial agreement). Dengan Putusan Mahkamah Konstitusi Nomor 69/PUU/XIII/2015, maka kedua belah pihak dapat membuat perjanjian baik sebelum maupun selama masih dalam ikatan perkawinan yang mana sebelumnya atau pada saat perkawinan 
dilangsungkan tidak membuat perjanjian perkawinan. Asalkan kedua pihak setuju dan perjanjian itu disahkan pegawai pencatat perkawinan atau notaris.

\section{Eksistensi Putusan Mahkamah Konstisusi Nomor 46/PUU/VIII/ 2010 dan Putusan Mahkamah KonstitusiNomor 69/PUU/XIII/2015 setelah adanya perubahan UU Perkawinan}

Mahkamah Konstisusi sebagai penjaga Konstitusi (de Guardian of the constution) dan sebagai penafsir Konstitusi (the soul interpreter of the constituation) telah melindungi hak dasar dalam Konstitusi sebagai kesepakatan bersama (general agreement) dimana setiap warga negara mendapatkan jaminan perlindungan, pemajuan, penegakan serta pemenuhan hak Konstitusionalnya. ${ }^{21}$ Melalui Putusan Mahkamah Konstisusi yang memperoleh kekuatan hukum tetap sejak diucapkan dalam sidang pleno terbuka untuk umum, sehingga sejak diucapkan dalam sidang pleno putusan Mahkamah Konstisusi wajib ditaati dan dilaksanakan oleh pemerintah, DPR, maupun masyarakat. Putusan Mahkamah Konstitusi bukan merupakan peraturan perundang-undangan (algemene verbindende voorschriften) namun dapat mengikat peraturan perundang-undangan.

Berkaitan dengan UU Perkawinan yang baru saja dilakukan perubahan sebagaimana dilihat berdasarkan konsideran perubahan UU Perkawinan tersebut salah satu terjadinya perubahan UU Perkawinan adalah melaksanakan amar Putusan Mahkamah Konstitusi Nomor 22/PUU-XV/2017 yang menyatakan “Memerintahkan kepada pembentuk undang-undang untuk dalam jangka waktu paling lama 3 (tiga) tahun melakukan perubahan terhadap UndangUndang Nomor 1 Tahun 1974 tentang Perkawinan (Lembaran Negara Republik Indonesia Tahun 1974 Nomor 1, Tambahan Lembaran Negara Republik Indonesia Nomor 3019), khususnya berkenaan dengan batas minimal usia perkawinan bagi perempuan". ${ }^{22}$

${ }^{21}$ Kepanitraan Dan Sekretariat Jendral Mahkamah Konstitusi, 'Mahkamah Konstitusi Menegakan Konstitusionalisme Dalam Dinamika Politik, Laporan Tahunan Mahkamah Konstitusi RI 2014' (Kepanitraan Dan Sekretariat Jendral Mahkamah Konstitusi, 2014).

22 Putusan Mahkamah Konstitusi Nomor 22/PUU-XV/2017. 
Ketentuan dalam UU Perkawinan yang diubah dalam Putusan Mahkamah Konstitusi Nomor 22/PUU-XV/2017 yaitu Pasal 7 ayat (1) UU Perkawinan yang semula menyatakan "perkawinan hanya diizinkan bila pihak laki-laki sudah mencapai 19 tahun dan pihak perempuan sudah mencapai 16 tahun", namun pasca Putusan Mahkamah Konstitusi Nomor 22/PUU-XV/2017 perubahan pada Pasal 7 ayat (1) UU Perkawinan menyatakan "perkawinan hanya diizinkan apabila pria dan wanita sudah mencapai 19 tahun".

Namun diketahui, jauh sebelum ada Putusan Mahkamah Konstitusi Nomor 22/PUU-XV/2017 sudah terdapat 2 (dua) putusan Mahkamah Konstitusi yang berkaitan dengan UU Perkawinan yang telah disebutkan diatas yaitu Putusan Mahkamah Konstisusi Nomor 46/PUU/VIII/2010 dan Putusan Mahkamah KonstitusiNomor 69/PUU/XIII/2015.

Dalam perubahan UU Perkawinan, Pemerintah dan DPR tidak mencantumkan perubahan ketentuan substansi pada pasal yang telah di ubah oleh Mahkamah Konstitusi berdasarkan Putusan Mahkamah Konstisusi Nomor 46/PUU/VIII/2010 pada Pasal 43 ayat (2) dibaca "anak yang lahir luar perkawinan mempunyai hubungan perdata dengan ibunya dan keluarga ibunya serta dengan laki-laki sebagai ayahnya yang dapat dibuktikan berdasarkan ilmu pengetahuan dan teknologi dan/atau alat bukti lain menurut hukum mempunyai hubungan darah, termasuk hubungan perdata dengan keluarga ayahnya" dan Putusan Mahkamah Konstitusi Nomor 69/PUU/XIII/2015 pada Pasal 29 ayat (1) UU Perkawinan "Pada waktu, sebelum dilangsungkan atau selama dalam ikatan perkawinan kedua pihak atas persetujuan bersama dapat mengadakan perjanjian tertulis yang disahkan oleh pegawai pencatat perkawinan ataunotaris, setelah mana isinya berlaku juga terhadap pihak ketiga sepanjang pihak ketiga tersangkut".

Jika melihat dari amar putusan kedua Putusan Mahkamah Konstitusi tersebut yaitu Putusan Mahkamah Konstitusi Nomor 46/PUU/VIII/2010 dan Putusan Mahkamah Konstitusi Nomor 69/PUU/XIII/2015 memang tidak menyatakan untuk memerintahkan kepada pembentuk undang-undang untuk melakukan perubahan pada UU Perkawinan, melainkan hanya melakukan 
perubahan pada ketentuan substansi pasal yang di ubah dalam UU Perkawinan, lain halnya pada amar Putusan Mahkamah Konstitusi Nomor 22/PUU-XV/2017 yang menyatakan memerintahkan kepada pembentuk undang-undang untuk melakukan perubahan pada UU Perkawinan tersebut dan melakukan perubahan pada Pasal 7 dan penambahan pada Pasal 65A UU Perkawinan.

Pemerintah dan DPR memiliki kewajiban untuk menindaklanjuti putusan mahkamah konstitusi sebagaimana pada Pasal 23 ayat (1) huruf b Undang-Undang Nomor 12 Tahun 2011 yang menyatakan dalam Prolegnas dimuat daftar kumulatif terbuka yang terdiri atas salah satunya akibat putusan Mahkamah Konstitusi. Selain itu sebagaimana pada Pasal 10 Undang-Undang Nomor 12 tahun 2011 yang menyatakan "salah satu materi muatan Undang-Undang adalah tindak lanjut dari putusan Mahkamah Konstitusi ". Berdasarkan Undang-Undang Nomor 12 tahun 2011, seharusnya Permerintah dan DPR tidak bisa hanya memilih satu putusan Mahkamah Konstitusi jika ada lebih dari 1 (satu) putusan Mahkamah Konstitusi yang merubah ketentuan substansi pada Undang-Undang yang terkait.

Dikaitkan dengan perubahan UU perkawinan tidak memuat kententuan pasal yang diubah pada UU Perkawinan berdasarkan Putusan Mahkamah Konstisusi Nomor 46/PUU/VIII/ 2010 dan Putusan Mahkamah KonstitusiNomor 69/ PUU/XIII/2015 tersebut melainkan hanya berdasarkan dari Putusan Mahkamah KonstitusiNomor 22/PUU-XV/2017 yang ada menyatakan "memerintahkan" untuk dilakukan perubahan pada UU Perkawinan. Padahal perjanjian prakawin dan status anak luar kawin juga menyangkut hak asas manusia, sebagaimana yang dijadikan dasar memasukan batas usia minimal kawin dalam melakukan perubahan UU Perkawinan. ${ }^{23}$ Sehingga menjadi sama-sama penting untuk dicantumkan dalam perubahan UU Perkawinan yang dilakukan Pemerintah dan DPR.

Akibat perubahan UU Perkawinan tersebut yang tidak ada menindaklanjuti Putusan Mahkamah Konstisusi Nomor 46/PUU/VIII/ 2010 dan Putusan Mahkamah Konstitusi Nomor 69/PUU/XIII/2015, maka eksistensi dari Putusan Mahkamah

${ }^{23}$ Muhammad Yasin, 'Revisi UU Perkawinan Disetujui, Dua Putusan MK Ini Terlewat' (Hukumonline, 2019). 
Konstisusi Nomor 46/PUU/VIII/ 2010 dan Putusan Mahkamah Konstitusi Nomor 69/PUU/XIII/2015 menjadi tidak kuat dalam pelaksanaan 2 (dua) Putusan Mahkamah Konstitusi tersebut setelah adanya perubahan UU Perkawinan.

Putusan Mahkamah Konstisusi Nomor 46/PUU/VIII/ 2010 dan Putusan Mahkamah Konstitusi Nomor 69/PUU/XIII/2015 seharusnya dicantumkan dalam perubahan UU Perkawinan berdasarkan Pasal 23 dan Pasal 10 UndangUndang Nomor 12 tahun 2011, dikarenakan kedua Putusan Mahkamah Konstitusi tersebut masih memerlukan peraturan perundang-undangan yang memperkuat dan mengakomodir terkait pelaksanaan kedua putusan Mahkamah Konstitusi tersebut, apalagi Putusan Mahkamah Konstisusi Nomor 46/PUU/VIII/ 2010 dapat di multitafsirkan.

Meskipun dalam perubahan UU Perkawinan tidak menindaklanjuti kedua putusan Mahkamah Konstitusi tersebut, tidakmenjadikan kedua putusan mahkamah konstitusi tersebut tidak memiliki eksistensi dalam pelaksanaannya dikarenakan semua putusan Mahkamah Konstisusi berlaku final dan mengikat setara dengan undang-Undang, sehingga apabila tidak dimuat dalam Perubahan UndangUndang tetap berlaku mengikat meskipun isi putusan Mahkamah Konstisusi tidak dimasukan dalam perubahan UU Perkawinan. Akibatnya eksistensi Putusan Mahkamah KonstisusiNomor 46/PUU/VIII/ 2010 dan Putusan Mahkamah KonstitusiNomor 69/PUU/XIII/2015 tersebut tetap berlaku sebagaimana mestinya dan ketentuan Pasal 29 dan Pasal 43 ayat (1) UU Perkawinan harus tetap dibaca dan berlaku sesuai denganPutusan Mahkamah Konstisusi Nomor 46/PUU/VIII/ 2010 dan Putusan Mahkamah KonstitusiNomor 69/PUU/XIII/2015.

\section{Kesimpulan}

Berdasarkan analisi tersebut diatas dapat disimpulkan bahwa Eksistensi Putusan Mahkamah Konstisusi Nomor 46/PUU/VIII/ 2010 dan Putusan Mahkamah Konstitusi Nomor 69/PUU/XIII/2015 setelah adanya perubahan Undang Undang Nomor 16 Tahun 2019 Tentang Perubahan Atas UndangUndang Nomor 1 Tahun 1974 Tentang Perkawinan tetap berlaku sebagaimana 
mestinya. Walapun perubahan UU Perkawinan hanya mengatur tentang usia Kawin dan tidak mengatur lebih lanjut Pasal 29 ayat (1), (3), (4) dan Pasal 43 (1) UU Perkawinan terkait status anak luar kawin dan Perjanjian perkawinan, namun ketentuan tersebut tetap berlaku karena semua putusan Mahkamah Konstisusi berlaku final dan mengikat setara dengan undang-Undang, sehingga apabila tidak dimuat dalam Undang-Undang Nomor 16 Tahun 2019 tetap berlaku mengikat meskipun isi putusan Mahkamah Konstisusi tidak dimasukan dalam perubahan UU Perkawinan. Dengan demikian, sepanjang tidak ada perubahan maupun pencabutan atas ketentuan mengenai anak luar kawin dan perjanjian perkawinantersebut, maka tetap harus dibaca dan berlaku sesuai Putusan Mahkamah Konstisusi Nomor 46/PUU/VIII/ 2010 dan Putusan Mahkamah Konstitusi Nomor 69/PUU/XIII/2015.

\section{Daftar Bacaan}

\section{Buku}

Bactiar, Problematika Implementasi Putusan Mahkamah Konstitusi Pada Pengujian UU Terhadap UUD (Raih Asa Sukses 2015).

Marzuki PM, Penelitian Hukum (2010).

Rasjidi LR\& IT, Pengantar Filsfat Hukum (2007).

Rahman S, Islam Moderat Menebar Islam Rahmatan Lil Alamin (Pustaka Ikadi 2007).

\section{Jurnal}

Agustine OV, ‘Politik Hukum Perjanjian Perkawinan Pasca Putusan Mahkamah Konstitusi Nomor 69/PUU/XIII/2015 Dalam Menciptakan Keharmonisan Perkawinan' (2017) 06 Rechts Vinding.

Jimly Asshiddiqie, 'Kedudukan Mahkamah Konstitusi Dalam Struktur Ketatanegaraan Indonesia' [2015] Berita Mahkamah Konstitusi Republik Indonesia.

Kepanitraan Dan Sekretariat Jendral Mahkamah Konstitusi, 'Mahkamah Konstitusi Menegakan Konstitusionalisme Dalam Dinamika Politik, Laporan Tahunan Mahkamah Konstitusi RI 2014' (Kepanitraan Dan Sekretariat Jendral 
150 | Lidya Mardiana, dkk: Eksistensi Putusan MK...

Mahkamah Konstitusi, 2014).

Nazaruddin lathif, 'Teori Hukum Sebagai Sarana/ Alat Untuk Memperbaharui Atau Merekayasa Masyarakat' (2017) 03 Pakuan Law Review.

Qomaruddin, 'Pembentukan Undang-Undang Dalam Perspektif Putusan Mahkamah Konstitusi' (2009) 6 Legislasi Indonesia.

\section{Laman}

Ahmad Dedy Aryanto, 'Perlindungan Hukum Anak Luar Nikah Di Indonesia' (2015) 9 Bilancia <file:///Users/mariajuanda/Downloads/283-Article Text-352-1-10-20180728.pdf $>$.

Muhammad Yasin, 'Revisi UU Perkawinan Disetujui, Dua Putusan MK Ini Terlewat' (Hukumonline, 2019).

How to cite: Lidya Mardiana, Sintia Anggrek dan Adeleda Patricia Djimat, 'Eksistensi Putusan MK Nomor 46/ PUU/VIII/ 2010 dan Putusan MK Nomor 69/PUU/XIII/2015 Setelah Adanya Undang-Undang Tentang Perkawinan Terbaru' (2020) Vol. 3 No. 1 Notaire. 